\title{
Commentary
}

\section{Dismissal of Disabled Employee not Discriminatory if Reasonable Accommodation Is Provided}

\author{
By Marlies Vegter, Labor Law Lawyer, Advisor and Researcher in Labor Law/ \\ Lecturer Labor Law at the University of Amsterdam (UvA), The Netherlands
}

\section{Background}

This case concerns whether dismissal of a worker on the basis of productivity, multiskilling, and absenteeism constitutes indirect discrimination within the meaning of Article 2(2)(b) of Directive 2000/78/EC if the worker has a recognized disability and therefore has difficulties meeting these criteria. The answer of the Court of Justice of the European Union (CJEU) appears straightforward: yes, the criteria are discriminatory if the employer has not provided reasonable accommodation for the worker; and, no, no discrimination is involved when it has been provided. However, in practice determining either can prove difficult. It is possible that an employer has taken appropriate measures, but that nevertheless a dismissal on grounds related to disability still affects a disabled employee more than others. In that case, it must be decided whether the employer's interests outweigh those of the employee or vice versa.

\section{Key Issues and Analysis}

Before the question about dismissal and reasonable accommodation can be answered, whether the employee concerned has a disability within the meaning of the directive needs to be assessed. The referring court asks whether the categorization of a worker as "being susceptible to occupational risks" under Spanish law means that the worker is disabled on the basis of the

(C) MARLIES VEGTER, 2020 | DOI:10.1163/24056901-00602017

This is an open access article distributed under the terms of the prevailing CC-BY-NC license at the time of publication. 
directive. ${ }^{1}$ The CJEU relays this question back to the Spanish court because such matters are decided by the national court rather than by the CJEU court. The CJEU uses the opportunity, though, to explain its case law on the definition of disability. The CJEU points out, as it did in HK Danmark, ${ }^{2}$ Daouidi $^{3}$ and Ruiz Conejero, ${ }^{4}$ among others, that the notion of disability in Directive 2000/78/ EC must be interpreted consistently with the UN Convention on the Rights of Persons with Disabilities (CPRD). That is, disability must be understood as referring to "a limitation of capacity which results in particular from long-term physical, mental or psychological impairments which, in interaction with various barriers, may hinder the full and effective participation of the person concerned in professional life on an equal basis with other workers." ${ }^{5}$ It is not required that a person is entirely unable to participate in a professional activity. The decisive issue is whether he or she is hindered by certain health impairments. This is in line with one of the main aims of the CPRD: full and effective participation and inclusion in society of people with a disability. ${ }^{6}$

The approach is also adhered to by the International Labor Organization (ILO) as part of its Future of Work agenda. ${ }^{7}$ The ILO endorses the human-rights based approach to disability, which emphasizes the importance of including people with disabilities in the workplace and the necessity of tackling the discrimination they face. In this respect, the CPRD, ILO, and CJEU take the same approach.

\section{Reasonable Accommodation and Dismissal}

The issue of reasonable accommodation is, as mentioned, a more complicated one. Article 5 of Directive 2000/78/EC stipulates that employers "shall take

1 Law 31/1995, the Prevention of Occupational Risks, Article 25.

2 CJEU, HK Danmark, acting on behalf of Jette Ring v. Dansk almennyttigt Boligselskab, Case C-335/11, and HK Danmark, acting on behalf of Lone Skouboe Werge v Dansk Arbejdsgiverforening, acting on behalf of Pro Display A/S, Case C-337/11, 11 April 2013, ECLI:EU:C:2013:222.

3 CJEU, Mohamed Daouidi v Bootes Plus SL and Others, Case C-395/15, 1 December 2016, ECLI:EU:C:2016:917.

4 CJEU, Carlos Enrique Ruiz Conejero v Ferroser Servicios Auxiliares SA and Ministerio Fiscal, Case C-270/16, 18 January 2018, ECLI:EU:C:2018:17.

5 CJEU, DWv Nobel Plastiques Ibérica SA, Case C-397/18, 11 September 2019, ECLI:EU:C:2019:703, para. 69 .

6 Convention on the Rights of Persons with Disabilities, see in particular Article 3, Principle 3.

7 Fundación ONCE and the ILO Global Business and Disability Network, "Making the future of work inclusive of people with disabilities," 22 January 2019, https:/www.ilo.org/wcmsp5/ groups/public/---ed_emp/---ifp_skills/documents/publication/wcms_729457.pdf. 
appropriate measures ... to enable a person with a disability to have access to, participate in, or advance in employment." This is seen as a necessary condition for creating equal opportunities. A Dutch author described this requirement as a true Aristotelian norm: disabled people must, to some extent, be treated unequally in order to bring them into the same situation as people without a disability, and, in that way, to create full equality. ${ }^{8}$ The directive itself does not outline which measures should be taken. In its preamble, the following examples are given: "adapting premises and equipment, patterns of working time, the distribution of tasks or the provision of training or integration resources." ${ }^{9}$ In HK Danmark, the CJEU points out that a reduction in working hours can also be seen as a reasonable accommodation. ${ }^{10}$ In national case law, examples include offering a lower position, if necessary with full pay, ${ }^{11}$ and buying a stair lift for a cashier who needed to go upstairs for the toilet and canteen. ${ }^{12}$

Not providing reasonable accommodation constitutes discrimination. Discrimination, however, does not necessarily mean that dismissal is prohibited. It is permissible if the disability and the dismissal are not related. An example is dismissal of all employees of a specific department for business reasons. Such a dismissal may include one or more disabled employees who happen to work in the department. In that event, the dismissal itself is not prohibited, but the employer may be required to take extra measures to protect the disabled employees in view of the difficulties they could face in finding new employment and financial repercussions related to their disability. ${ }^{13}$

If no reasonable accommodation has been provided, dismissal on superficially neutral grounds that could disadvantage disabled employees is definitely discriminatory. Were the Spanish court, following the CJEU finding, to decide that the employee concerned is disabled and that the employer did not take appropriate accommodating measures, its ruling would find discrimination. Such a decision appeals to a sense of justice. A different outcome would mean

8 P. C. Vas Nunes, Gelijke behandeling in arbeid (Equal Treatment in Employment), The Hague, 2018, 669.

9 Preamble no. 20.

10 HK Danmark, paras. 48-64.

11 UK Employment Appeal Tribunal, 26 August 2016, G4S Cash Solutions Ltd v. Powell (2016), UKEAT 0243_15_2608.

12 NL District Court's-Hertogenbosch, 24 May 2012, JAR 2012/199.

13 See CJEU, Johann Odar v. Baxter Deutschland GmbH, Case C-152/11, 6 December 2012, ECLI:EU:C:2012:772, para. 69 . 
that the employee would be disadvantaged twice: first because no reasonable accommodation was provided and second because of dismissal on the basis of discriminatory criteria.

In the event that the employer has provided reasonable accommodation, different situations may unfold. Accommodation has actually created equal opportunities for the disabled employee relative to those without disabilities. In that situation, even dismissal related to productivity, employability, and sick leave is not discriminatory. At the other end of the spectrum, the employer has provided reasonable accommodation but the employee is still not able to complete the work. In such situations, dismissal is allowed, either on neutral grounds with no relation to disability or on possible indirect discriminatory grounds, as productivity, employability or sickness absence, or even directly on the basis of the disability itself. As the CJEU points out in Nobel Plastiques, "the directive does not require the recruitment, promotion or maintenance in employment of an individual who is not competent, capable and available to perform the essential functions of the post concerned, without prejudice to the obligation to provide reasonable accommodation for people with disabilities" (para. 74).

Unfortunately, nothing in day-to-day life is always as clear as in theory. It is quite possible that an employer has taken reasonable measures but not created circumstances in which the disabled employee could function comparably to his or her colleagues, not because the employee cannot perform the essential functions of his or her job, but because the employer is not required to take more far-reaching measures. In such circumstances, the employer has done his duty but dismissal on grounds of disability is still discriminatory. The judgment in Nobel Plastiques seems to imply that in those circumstances the interests of the employer prevail, but this outcome is not entirely certain. ${ }^{14}$ Perhaps the same approach as for dismissal of a disabled employee on neutral grounds applies here: no prohibition of the dismissal as such, but either extra help for the employee to find work elsewhere or compensation for the financial requirements arising from a disability must be provided..$^{15}$

14 Nobel Plastiques, paras. 73 and 74; see also N. Gundt, "Indirecte discriminatie op grond van handicap en redelijke aanpassingen" (Indirect discrimination on the ground of disability and reasonable accommodation), TRA 2019/122.

15 CJEU, Johann Odarv. Baxter Deutschland GmbH, Case C-152/11, 6 December 2012, ECLI:EU: C:2012:772, para. 69 . 


\section{Conclusions}

The judgment in Nobel Plastiques has brought more clarity to the relationship between the obligation of the employer to provide reasonable accommodation and the permissibility of dismissal on grounds of disability. The question whose interests prevail when reasonable accommodation has been provided, but has not created equality for the disabled worker, however, remains to some extent unanswered. 